\title{
The Saudi Political System and the Calculations of the New Balances in the Middle East
}

\author{
Abdullah H. Othman \\ Peoples' Friendship University of Russia (RUDN University), \\ 6, Miklukho-Maklaya Str., Moscow, Russian Federation, 117198 \\ \abdollah.othman1985@gmail.com
}

\begin{abstract}
This article highlights the role of Saudi Arabia in the process of regional integration and the establishment of new balances of power in the Middle East. Saudi Arabia is arguably one of the most important states in the region in terms of power, economy and diplomacy. Its power is not only limited to political influence, but also carries with it religious dimensions that helped to shape and escalate regional situation as manifested through Saudi Arabia's attempts to contain non-Arab forces to establish privileged relations with them from a national or Islamic perspective .Saudi Arabia has stepped up military agreements to ensure regional balance in the Middle East, one of the most important international regions. The stability of the region is considered to be of international concern. It is against this backdrop that Saudi Arabia competes for influence in the Middle East. In addition to the events of September 11, 2001, which negatively affected the relationship between Saudi Arabia and the United States of America, especially after the accusations made by the United States against Saudi Arabia and accused it of supporting the perpetrators of the September 11 attacks, the relationship between the United States and Saudi Arabia was strained. Saudi Arabia began to look for a new partner that would have considerable political weight, and in Russia found what it was looking for. The relationship between Saudi Arabia and the Russian Federation began to develop gradually despite the absence of political exchange and cooperation between the two parties for a long time, and this relationship took the form of expansion to include the field of diplomatic representation and the conclusion of economic and oil agreements and in various other fields represents the political rapprochement between the two countries.
\end{abstract}

Keywords: Saudi Arabia, political system, Regional balance, the Middle East, Terrorism

Conflicts of interest: The author declared no conflicts of interest.

Article history:

The article was submitted on 28.04.2021. The article was accepted on 31.05.2021.

\section{For citation:}

Othman A.H. The Saudi Political System and the Calculations of the New Balances in the Middle East. RUDN Journal of Public Administration. 2021;8(3):336-346. DOI: 10.22363/2312-83132021-8-3-336-346

\section{Introduction}

The Kingdom of Saudi Arabia is pursuing active external policies that have an impact on both regionally and globally. Its foreign policy potential is associated with great economic and financial capabilities, determined by the position of the 
largest supplier of hydrocarbons to the world market. Moreover, the Saudi kingdom identifies itself as the centerpiece of the Muslim community. A convincing confirmation of this is the fact that the Saudi king acts as the patron saint of the holy places of Islam in Mecca and Medina, located to which over two million Muslims make pilgrimages every year. Another important component of the selfidentification of the Saudi state is its belonging to the Arab world. In the Arab political space, the role of Saudi Arabia is great because in many of its parameters it occupies a leading place in this space and justifiably claims to be the central link of the Arab geopolitical community [1].

The regional reality in the Middle East imposes the presence of rising powers trying to impose their agenda and extend their influence in the region to control the decision in it, protect its supreme interests, preserve its stability and protect its borders, so the Kingdom of Saudi Arabia is trying to build a military capacity to create a strategic military balance with Iran in the Middle East region in general, and the Arab Gulf in particular, it prevents it from imposing its conditions in the regional security system in the Arab Gulf and the Middle East region.

The Kingdom of Saudi Arabia suffers from a complex crisis (internally externally), which has led to several problems it faces is how to contain it, and the search for mechanisms to keep things out of control, The changes that have occurred in the region recently are pushing towards narrowing the options of the Saudi foreign policymaker because it has intended since the formation of the Kingdom on a single ally, and the flexibility and pluralism are no longer in foreign dealing, As a result, foreign policy has been hit by the predicament of the inability to adapt, as well as the adoption of principles contrary to what is in international relations, which is the sectarian engine in the compass of its relations, directions, and objectives, towards all international units, which is no longer commensurate with the realities of the Twenty-First Century. The article relies on several sources, publications, and books, by shedding light on the Saudi political system and the calculations of the new balances in the Middle East, and among the most important works of Arab researchers such as (M. Al-Saeed, H. Hamdan, and A. Al-Tai) who describe the regional balance in the Middle East region, in addition to The most important foreign researchers such as (E.L. David, F. Herman), we should focus in this article on the most important works of Russian researchers who study the political situation in the Middle East, and Russian-Saudi relations in the region, such as (G.G. Kosach, E.S. Melkumyan, T. Dmitri, M.N. Katz ).

In the article titled (The Saudi political system and the calculations of the new balances in the Middle East), we reviewed the first topic "The nature of the political system in Saudi Arabia" and in the second topic we dealt with "Regional balances in the Middle East" and in the third topic we talked about "Saudi position on international terrorism".

\section{The nature of the political system in Saudi Arabia}

The alliance between the Saudi family (Al-Saud) and their partners, the Wahhabi scholars, began in 1744, when Muhammad bin Saud, who died in 1765, a tribal leader from (AL-Diriyah) in the central region of the Arabian Peninsula (Najd) and Muhammad bin Abdulwahab 1703-1792, who was an extremist religious reformer From the same region, with cooperation, the Arabian Peninsula was subjugated, and the Al Saud formed the political and military leadership in this 
alliance, while the Wahhabi scholars, especially those of the Muhammad bin Abdulwahab dynasty, formed the religious leadership [2].

The Kingdom of Saudi Arabia was established as a state based on the existing borders in 1932 through the issuance of a royal decree by King Abdul-Aziz bin Saud, according to which he defined the two emirates (Najd and Hejaz) and their annexes to announce the establishment of the Kingdom of Saudi Arabia and the title of King and his successors after he became the King of the Kingdom of Saudi Arabia. The designation shows that the political system in Saudi Arabia is a monarchy. The ruling family has absolute power in the political decision-making process and controls the three powers (executive, legislative and judicial). The Saudi regime derives its legitimacy from two main 4sources (Islam and tribal traditions) [3].

Article 5 of the Basic Law of the Kingdom of Saudi Arabia stipulates: the system of government in the kingdom of Saudi Arabia is royal and the rule shall be in the Sons of the founding King Abdul-Aziz bin Abdurrahman Al-Faisal Al-Saud and Sons of sons. The King chooses the crown prince and exempts him by royal order and the Crown Prince assumes the King's powers upon his death until the sale is completed and the citizens sell the King on the book of God and the year of his messenger and on hearing and obedience and Saudi political system is based on the tribal alliance, which is carried out through intermarriage with some of the major tribes in the kingdom, for example, King Abdulaziz used the method of intermarriage with some of the families that make up the pillars of the kingdom, such as (Al-Sheikh, Al-Jalawi, al-Sudairi, and Al-thaneyan) [4]. However, the (Al Saud) tribe, whose number ranges between $(5,000,7,000)$ princes and princesses, has controlled the kingdom's capabilities since its inception, with the help of some other families with a clear and influential role in the Kingdom[5]. The political decision-making process in Saudi Arabia is dominated by three institutions that are in descending order of importance:

The Consultative Council: which consists of (60-90) members and does not exceed being a council of an advisory capacity whose members are appointed by the king and accountable to him and not the people? Therefore, it has a limited influence on the decision-making process in the Kingdom [6]. Religious scholars have a clear role to play in the design of social policies, the enactment of legal acts and religious guidance throughout the Kingdom, the supervision of religious education in the Kingdom's schools, and the advocacy of Islam abroad [7].

Article 44 of the Statute provides that the powers of the State shall consist of the judiciary, the executive, and the regulatory authority. These authorities cooperate in the performance of their functions by this system and other regulations, and the king is the reference of these authorities [8]. The Saudi political system is concentrated on the person of the King, who combines the religious authorities as to the Custodian of the Two Mosques with the political authorities. The position of the King is at the top of the Saudi Arabian political system for these political institutions. Therefore, the only person among the main figures in the political system that participates in most decisions as President of the executive and legislative branches [9]. The Council of ministers is officially the third authority in the state after the authority of the king and the crown prince and performs the legislative and executive functions, in addition to its important influence in the 
foreign policymaking of the kingdom of Saudi Arabia, which is stipulated in Article (18) of the council's 1958 regulations, which emphasized that the Council of Ministers shall formulate internal, foreign, financial, economic, educational and defense policy. International treaties and conventions are not considered to be in force only with his consent, and his decisions are final unless required to issue a royal decree [10]. Thus, the Council has become one of the most powerful organs of the Saudi political system, and it enjoys wide powers and derives its strength through its very close association with the king after he became the king and since the assumption of King (Faisal) is the Prime Minister and the Crown Prince as his deputy [11].

From all of the above, it is possible to establish some of the characteristics of the political system in the Kingdom of Saudi Arabia, as follows:

1. It is a closed, hereditary family political system in which the throne is inherited after the death of King Abdel Aziz among the brothers according to their age order, and is therefore distinct from the other royal regimes in which the throne is inherited from the king to his son after him [12];

2. The reins of power in it are under the control of powerful and influential families, as it is directed by these families, the most important of which is the (Al Saud) tribe, which is a modern extension of the ancient tribal families and traditions, in addition to religious scholars, the most prominent of whom come from members of the (Sheikh) family, descended from the core of the founder of the movement Wahhabis' (Muhammad Ibn Abd al-Wahhab) [13].

\section{Regional balances in the Middle East}

By looking at the balance of power in the Middle East region, there are a series of overlapping crises in regional and international conflicts in the Middle East region, since the parties to the regional conflict are clear and can be characterized in two non-static camps, the first being the Turkish Gulf American party, the United States ally in the Zionist entity and the other being the Syrian Government, Iran, and Russia and if not witnessed by a declared Israeli-Gulf coalition, but interests may come together in the face of the extension of Iranian influence in the Middle East by beating its allies in the region because Iran is a large state and has significant military capabilities that have made the international community eager to restrict its missile capabilities, as well as its access to nuclear capability if its nuclear program can operate, develop and continue. So that no one state alone can counter Iranian power. Therefore, Saudi Arabia cannot confront Iranian power, and Israel and Saudi Arabia seem to regard Iran as the greatest threat.

Although Turkey may not focus on Iran to the same extent, it is concerned about the growth of Iran at the regional level, but Turkey has left this AmericanSaudi camp due to recent disagreements over several issues, the most important of which is the failed coup that took place in Turkey in 2016, which is accused Turkey in the Turkish opposition (Fethullah Gulen) residing in the United States of America that behind the coup, Which caused the United States of America (Gulen) not to hand over to Turkey, which led to the deterioration of Turkish-American relations, and a shift in Turkish foreign policy towards Russia and Iran, and at the same time, the Kingdom of Saudi Arabia is engaged in a foreign policy in which the Arab League is represented through the coalition that it leads in Yemen and elsewhere. In an attempt to repel Iranian influence and keep its danger away from 
it and its interests, and on the other hand, Iran is the most influential player In Iraqi, Syrian, Lebanese and Yemeni politics. Efforts by other regional forces to counter Iranian gains have all failed, whether it be Turkish and Saudi support for the Syrian opposition, Saudi funding for the 14 March Coalition of the Forces in Lebanon and military assistance to the Lebanese government, or the current Saudi air campaign against the Houthi group in Yemen. Efforts by other regional forces to counter Iranian gains have all failed, whether it is Turkish and Saudi support for the Syrian opposition, Saudi funding for the 14 March Coalition of the Forces in Lebanon and military assistance to the Lebanese government, or the current Saudi air campaign against the Houthi group in Yemen [14].

The United States of America believes that Iran represents a major threat to Israel's security and to maintaining Israel's military and technological superiority in the Middle East. The United States of America has tried to contain Iran and prevent it from becoming a central power by imposing economic sanctions on Iran. However, Iran has succeeded in creating a large regional force, yet it is aware of the gravity of the Arab-backed American position of Saudi Arabia and a new economic blockade imposed by the President (Donald Trump) On Iran to whistle at the level of Iranian oil exports on world markets, to prevent all countries from buying Iranian oil, to surround Iran economically to bring Iran to the negotiating table, and to prevent it from supporting its regional arms.

\section{Saudi position on international terrorism}

1. U.S.-Saudi relations soured after September 11, 2001 attacks The date of the emergence of the term international terrorism is after the attacks that struck the United States of America on September 11, 2001, and even though the US-Saudi relations are characterized by the highest level of friendship and political, economic, military, and security alliance, they were subjected to shaking and confusion, which led to a cooling in the relationship between them because of International terrorism. The Kingdom deals with the means and tools of this issue until the mid-nineties of the last century, after the bombings that targeted it in (1995) and (1996) [15].

Several deep problems have emerged within the Kingdom, including the frustration of the majority of Saudi society and the growing state of social contradiction in the Saudi society as a result of the conflict between traditional Islamic values and Western secular values, which is a contradiction that comes from social, economic and political development programs in light of the government's endeavor to modernize the state at a time In it, the Kingdom witnessed austerity measures under low oil prices and the achieved revenues [16]. As for externally, the presence of American forces on Saudi soil had the greatest impact on the growth of this phenomenon [17]. This military presence, while fulfilling its stated objectives for many years to protect the Kingdom, on the other hand, has threatened the legitimacy of the Kingdom's political system and has raised several questions about the extent to which the United States of America is committed to defending the Kingdom if it is subjected to a threat that does not pose a threat to its interests, particularly that which could be achieved by Israel [18].

Accordingly, this military presence in the Kingdom of Saudi Arabia provoked the sensitivity of several well-known religious scholars in the Kingdom, and more than that, an Islamic opposition group in the Kingdom called in (1993) calling itself 
(the Committee for the Defense of Legitimate Rights) to elect a government that represents the people and to the strict application of Islamic law and ending the rule of the royal family [19]. Amid these interactions, the events of (September 11th) came to place the Kingdom of Saudi Arabia in a confrontation with the issue of international terrorism, especially with the United States of America, for several considerations, perhaps the most important of which are:

1. Saudi Arabia has a special relationship with the United States of America, but how the United States is dealing with the issue of international terrorism has put Saudi Arabia in a very difficult position, especially since it turns out that the majority of them have carried out operations 11 September is more important than Saudi Arabia's citizen [20], and most importantly: Osama bin Laden is behind the terrorist operation, so this crisis has put the Kingdom of Saudi Arabia in a critical position [21].

2. The religious influence of Wahhabi thought dominates the political and military institutions of Saudi Arabia. It is known that one of the most important pillars of Saudi Arabia's political system is Islamic ideology based on the views of a movement (Mohammed bin Abdul Wahab) The United States of America has therefore developed this correlation. (Religious - Political) In the position of the divisions after the will of the commander of the perpetrators of the attacks (She'd Atta) has been published it is full of terrorist vocabulary urging the hatred of nonMuslims in the Islamic nation and the education of Saudi children in public schools to hate Americans, and this hostile attitude to non-Muslims is repeated in religious sermons, television programs, and the Internet [22].

\section{The impact of the events of September 11 on Saudi-Russian relations}

Over the past decade, Russia activated relations with the conservative Gulf monarchies, virtually nonexistent in the times of the Soviet Union; at the top of the list came Saudi Arabia. Moscow clearly understood the importance and prestige in the Muslim world of the country that had the holiest Muslim sites in its territory. In an effort at procuring international legitimacy for the Moscowloyal Chechen leaders, the Kremlin organized their pilgrimages to Mecca, which is now regularly visited by thousands of Russian Muslims. Russia also wanted to make sure there was no Saudi support to the radicals in the Muslim republics in the North Caucasus or on the Volga. As Russia and Saudi Arabia are the world's number one and number two oil exporters [23].

The deterioration in the relationship between the United States and the Kingdom of Saudi Arabia due to the data we mentioned prompted the Saudis to search for a new partner that would be the size of the United States, and the Kingdom began to move towards establishing new relations with the Russian Federation, and Russia, on its part, required strengthening and strengthening Its presence in the Arab Gulf region, especially in light of the isolation imposed on its former allies in the region, such as Libya, Syria, and Iraq, following the war launched by the United States over what it described as terrorism [24]. The Saudi trend towards developing cooperation with Russia was built based on its strained relationship with the United States, because after the events of September 11, the United States began to put pressure on Saudi Arabia through political control of Saudi oil exports, and there were also indications that a section of Saudi society began to express its regret. By reference to the weakness of the Russian position 
in the Middle East since the beginning of the nineties, and Saudi public opinion has shown its dissatisfaction with the American military and political presence in the region [25]. Because of the urgent need to strengthen the relationship of the Kingdom of Saudi Arabia with Russia, Saudi Foreign Minister Prince Saud Al-Faisal paid a working visit to Moscow on April 18, 2002, and his discussions with his Russian counterpart, Igor Ivanov, focused on the situation in the region and in Iraq and Palestine and ways to achieve the Beirut-Saudi initiative on the Middle East. Al-Faisal met during his visit with Russian President Vladimir Putin and in response to the visit of the Saudi Foreign Minister, Russian Assistant Foreign Minister Anatoly Safonov visited Saudi Arabia a month after Prince Saud Al-Faisal visited Moscow, which included the Russian delegation. Representatives of various government ministries, government departments, legal bodies and specialists in combating so-called terrorism, and during the discussions held by the Russian delegation with the Saudi Foreign Minister and Minister of Interior Prince Nayef bin Abdul-Aziz and their assistants, many cooperation frameworks in the field of combating terrorism were discussed, including the agreement on an effective system to prevent the arrival of The funds were transferred to what they called terrorist organizations, In order to strengthen relations between the two sides, Saudi Foreign Minister Saud Al-Faisal visited Moscow on May 8, 2003 for the purpose of preparing for the visit of the Crown Prince of the Kingdom of Saudi Arabia, Prince Abdullah bin Abdul-Aziz in Moscow, and Prince Abdullah visited Moscow on September 3, 2003, and his visit lasted for three days, and this visit opened the door wide for Entering a new phase of close cooperation between the two sides, that visit was motivated by the future concerns of Saudi Arabia in the wake of the American occupation of Iraq [25].

Therefore, obtaining support from a great country like Russia, which is widely respected, is of great importance in the framework of efforts aimed at avoiding any future dangers similar to those faced by Iraq. Joint committees were formed to deal with issues related to combating terrorism and to coordinate the efforts of the two countries in this aspect. In its endeavor to frame its new approach, Russia expressed its desire to strengthen its relations with the Arab world, and the most telling witness to this trend was the statement made by Russian President Putin in August 2003, in which announced that his country was considering joining the Organization of the Islamic Conference despite the lack of Russia's eligibility for membership in the organization, as its laws stipulate that the percentage of Muslims in the country entitled to membership should not be less than $25 \%$ of the total population, but it may depend in the success of its endeavors on its relationship with the Gulf countries that seemed to support the Russian effort, which is This was reflected in the press release issued by Fouad Al-Khatib, the Saudi Minister of Information, and published by one of the Russian daily newspapers, in which hinted that Saudi Arabia might provide support to Russia in the event that it submits an official request to join the Organization of the Islamic Conference. Thanks to Saudi support, Russia was able to join the Organization of the Islamic Conference as an observer in 2005 [26].

There is no doubt that Russia will invest its accession to the organization regarding the Chechen issue, to which Russia feels that it is being targeted according to its allegations by a terrorist war, and believes that effective 
cooperation with the Arab Gulf train, especially the Kingdom of Saudi Arabia, will help to intensify the dialogue between Russia and the Islamic nation, in addition to what can be added. Saudi Arabia plays as a source of inspiration for about 20 million Russian Muslims [27]. The development of the Saudi-Russian relationship prompted Russian President Vladimir Putin to consider visiting Saudi Arabia. To prepare for this visit, Russian Foreign Minister Sergei Lavrov visited Riyadh in May 2006 to prepare for Putin's visit, and for its part, the Kingdom of Saudi Arabia welcomed the visit of the Russian President, and to indicate the prior gestures of welcome, Prince Khaled Al-Faisal, Chairman of the King Faisal International Prize Authority and the Prince of the Asir region announced on 13 January 2008 that the commission decided to award the King Faisal International Prize for the Service to Islam to the President of Tatarstan Mintimer Shaimiyin, as reported by the Saudi newspaper Okaz, which considered Tatarstan a manger of social and peaceful coexistence and a symbol of tolerance, and Putin mentioned in his annual press conference in February 2007 in Moscow about his expected visit to Saudi Arabia, Qatar, and Jordan, and he indicated that the Russian interest in the Middle East region has always been great, and Russia's relations with it are historical [28].

Russian President Vladimir Putin visited Saudi Arabia on February 11, 2007, and this was the first visit by a Russian president in 80 years, during which he pledged to strengthen Russia's relations with the Islamic world, and both President Putin and King Abdullah bin Abdul-Aziz presided over the talks that took place between the two sides, and King Abdullah affirmed the strength The relationship, noting that Russia was the first country to recognize the Kingdom of Saudi Arabia, and Putin assured that he is a friend of the Kingdom of Saudi Arabia and the Custodian of the Two Holy Mosques. During the talks, the two sides discussed developments on the international regional arenas, foremost of which is the Palestinian issue and the situation in Iraq, in addition to prospects for cooperation between the two countries [29]. Since 2003, the positive development of Saudi-Russian relations has reached an unprecedented level. The countries have exchanged a series of high-level visits, including Crown Prince Abdullah's visit to Moscow and President Putin's visit to Riyadh in February 2007. The Kingdom of Saudi Arabia also visited the Kremlin-appointed President of Chechnya, Ramzan Kadyrov. LUKoil and some other Russian companies are currently operating in Saudi Arabia. Trade between the two countries increased from a negligible pre-1990 level to $€ 336.8$ million in 2008 . It has also been repeatedly reported that Riyadh may soon begin purchasing Russian weapons [30].

The step to strengthen the relationship with Russia comes as part of the openness policy pursued by the Kingdom of Saudi Arabia, as the latter seeks to use its relations with Russia in the service of its national interests, especially the Palestinian cause, and the Kingdom hopes in Russia to have a strong and active presence in this issue, especially since Russia is one of The international quartet sponsoring the peace process. The same applies to the Iraq issue, whose impact has now been reflected in the neighboring countries, and the region has become unstable as a result of the occupation and its failure to properly address the situation in Iraq [31]. 


\section{Conclusions}

Saudi Arabia's competition for control in the Middle East has a significant impact on the stability of the region, as it represents the most influential power in the East, because of its human capabilities and economic and political potential that affect the security and stability of the region.

Saudi Arabia's cooperation towards the region is leading to economic prosperity and security stability, while tension is creating instability, which has been planned in recent years when Al Qaeda and ISIS took control of large parts of Iraq and Syria and planned to destroy the entire region, to make the Zionist entity the strongest regional entity after destroying the military infrastructure of the States of the region and weakening military capabilities and destroying them in domestic wars and This led to the transformation of Saudi-Iranian relations into high levels of tension and conflict accompanied by ideological extremism, giving them a greater dimension, which led to the widening of the gap and the spread of conflicts in the Middle East region.

It can be said that Saudi Arabia created a Gulf and Arab military alliance to defend the legitimacy in Yemen, and to strike the Houthi military rebellion, in a clear signal to Iran, that the kingdom has become more daring and attentive in its foreign political and military moves, a matter that confused Iran's calculations at the strategic level, and even restored The case is to evaluate its role in supporting its allies in the region, which created a new equation in the midst of the conflict in Syria, in terms of compensation for the loss in Yemen, and even opened the door to geopolitical changes completely different from what was expected for the international powers affecting the region, especially the United States, In terms of deepening the state of strategic weakness in the Middle East, to preserve its alliances and safeguard its interests.

The relationship that arose between Saudi Arabia and Russia will have a great deal, as the two countries are on the throne of global oil exports, and if the oil policy of these two countries is united, they will control the fate of many countries of the world due to the importance of oil in political conflicts.

The reaction that appeared after the events of September 11th from the Saudi people towards the United States of America represented a major inflection point because the Saudi people demanded their government to change its policy towards the United States and to work on building new relations with Russia.

The important point that must be addressed is that the Russian-Saudi rapprochement if it were to continue and develop into military and strategic agreements, may isolate the growing Iranian ambitions that threaten the Arab Gulf region by encircling it and limiting its role, similar to the agreements that were previously The United States shall hold it with the countries surrounding the former Soviet Union to isolate it from the surrounding countries.

\section{REFERENCES}

[1] Kosach G.G., Melkumyan E.S. The Foreign Policy of Saudi Arabia: Priorities, Directions, Decision Process. Moscow: RSUH; 2003.

[2] Brigitte M. Contemporary Sunni-Shiite Relations, Baghdad: 2018:48.

[3] David E.L. The Persian Gulf. Colorado: Westview Press; 1988. 
[4] Al-Saeed M. The Regional System of the Arab Gulf. Beirut: Center for Arab Unity Studies; 2000.

[5] The Basic Law of Governance in the Kingdom of Saudi Arabia. 2010:11. URL: https://nshr.org.sa/wp-content/uploads/2013/10/528.Pdf. Accessed: 10.04.2021.

[6] Al-Alikim H.H. The Environment of Saudi Foreign Policy-Making. The Arab Journal of Political Science. 1994;117:47.

[7] Al-Saeed M. The Regional System of the Arab Gulf. Beirut: Center for Arab Unity Studies; 2000.

[8] Al-Najjar G. The Reality and Future of the Political Situations in the Gulf Countries. Arab Future Magazine. 2001;269:104.

[9] Gregory F.G. Why No Alliance Against Iran. 2015. URL: https://www.brookings.edu. Accessed: 11.04.2021.

[10] Farsi F. The Saudi Model in Development: A Case Study. Journal of Gulf, and Arabian Peninsula Studies. 1999;128:150.

[11] The Basic Law of Governance in the Kingdom of Saudi Arabia. URL: https://www.saudiembassy.net/basic-law-governance. Accessed: 22.03.2021.

[12] Ahmed A.N. The System of Government in the Kingdom of Saudi Arabia: A Study of Political Developments and Future Options. Baghdad: The University of Baghdad; 1998.

[13] Muhammad Bin S. The Saudi Elite: A Study of Transformations and Failures. Beirut: Center for Arab Unity Studies; 2004.

[14] Qais M.N. Society and the State in Saudi Arabia: The March of Half a Century, Baghdad: House of Wisdom; 2001.

[15] Muhammad B.D. The Origin of the Terrorist Problem in the Kingdom of Saudi Arabia. Doha: Al-Jazeera satellite channel; 2015.

[16] Al-Mani S.A. Global Relations of the Cooperation Council for the Arab States of the Gulf: The Emerging Reality and the Arab Future Magazine. Beirut: Center for Arab Unity Studies; 2001:165.

[17] Herman F. Saudia and the United State: Birth of Security Partnership. Indianapolis: Indiana University Press; 1998.

[18] Neil G. Secrets of Wars: The Wars of a Whole Century and the First Wars of the Twentieth Century. Beirut: Dar Al-Hussam Printing and Publishing; 2003.

[19] Ahmed I.M. The New Terrorism: The Main Form of Armed Conflict in International Relations. Journal of International Politics. 2001;147:50.

[20] Patterns of Global Terrorism Released by the Office of the Coordinator for Counter Terrorism. 2001. URL: http://www.unsifo.state.gov./ar/home/products. Accessed: 22.03.2021.

[21] The Charge against International Terrorism, Usama bin Laden. U.S. Department of state. URL: http:/www.whitehouse.gov/news/releases/. Accessed: 12.04.2021.

[22] Ibrahim G. America and Saudi Arabia: Media Campaign or Political Confrontation? URL: http://www.aljazeera.net/nr/exeres/.Accessed:11/3/2002. Accessed: 22.03.2021.

[23] Dmitri T. Russia's Policy in the Middle East: Prospects for Consensus and Conflict with the United States. New York: The Century Foundation Report; 2010.

[24] Ayla A. Relations between the Gulf States, the Gulf Cooperation Council, and Russia, "Gulf Researchers Group in 2003. Dubai: published by the Gulf Research Center; 2004.

[25] The Countries of the Arab World and Russia Today. The Kingdom of Islam between East and West. URL: http://www.russarabc.ru:/arab/. Accessed: 21.03.2021.

[26] Al-Riyadh Al-Youm Newspaper, Counter. URL: http://www.Alriyad -np.com\13845,12/5/ 2006. Accessed: 21.03.2021.

[27] Abdul Razzaq K.M. The Arabian Gulf in Contemporary Russian Strategy. Mosul: University of Mosul; 2007.

[28] Russian-Saudi Relations: Decades of Convergence and Separation. URL: http://www.ceea.com/ar/details. Accessed: 21.03.2021.

[29] The Russian President Sees Opportunities for Peaceful Nuclear Cooperation, Launching 6 Saudi Satellites. URL: http://www.Alriyad-np.com. Accessed: 21.03.2021.

[30] Katz M.N. Saudi-Russian Relations since the Abdullah-Putin Summit. Middle East Policy Council. 2007;4:152-157.

[31] Muhammad A.Y. Saudi-Russian Relations in Light of the Visit of Russian President Vladimir Putin to the Kingdom of Saudi Arabia. Regional Follow-up Bulletin. Vol. 4 issued by the Center for Regional Studies. Mosul: University of Mosul; 2007. 
Information about the author:

Abdullah H. Othman - PhD student of the Department of Political Analysis and Management, Faculty of Humanities and Social Sciences « Peoples' Friendship University of Russia (RUDN University) (Russian Federation) (ORCID ID: 0000-0003-1875-8867) (e-mail: abdollah.othman1985@gmail.com).

\title{
Политическая система Саудовской Аравии и формирование нового баланса на Ближнем Востоке
}

\author{
А.Х. Отман \\ Российский университет дружбы народов, \\ 117198, Россия, Москва, ул. Миклухо-Маклая, 6 \\ $\triangle$ abdollah.othman1985@gmail.com
}

\begin{abstract}
Аннотация. В данной статье подчеркивается роль Саудовской Аравии в процессе установления нового регионального баланса на Ближнем Востоке, поскольку она является одной из самых ярких стран региона в области управления, экономики и дипломатии, которая не ограничивается политическим влиянием, но также включает в себя религиозные аспекты, которые способствуют кристаллизации регионального статуса страны. Саудовская Аравия стремится поддерживать контакты с неарабскими державами, чтобы установить с ними взаимовыгодные отношения с учетом своих национальных или религиозных интересов. Отдельно подчеркивается роль Королевства Саудовской Аравии в подписании военных соглашений для обеспечения регионального баланса на Ближнем Востоке, что имеет большое значение и на международном уровне. Стабильность в данном регионе считается основой международной стабильности Королевство Саудовская Аравия выстраивает свою политику в регионе Ближнего Востока на основе стремления к стабильности, балансу, безопасности и сотрудничеству. После событий 11 сентября 2001 года, которые негативно повлияли на отношения между Королевством Саудовской Аравии и Соединенными Штатами Америки, особенно после обвинений, выдвинутых Соединенными Штатами в адрес Саудовской Аравии, в поддержке виновников теракта, Саудовская Аравия начала поиск нового партнера, который имел бы большой политический вес, и нашла его в лице России. Отношения между Саудовской Аравией и Российской Федерацией начали постепенно развиваться, несмотря на отсутствие политического обмена и сотрудничества между двумя сторонами в течение длительного времени, и эти отношения принимают все более широкую форму, включившего сферу дипломатического представительства и заключения экономических договоров в нефтяных и других областях. Прогресс в отношениях между Россией и Саудовской Аравией лишь усилился после визита Президента России Владимира Путина в Саудовскую Аравию в феврале 2007 года, который был представлен политическим сближением между двумя странами.
\end{abstract}

Ключевые слова: Саудовская Аравия, политическая система, региональный баланс, Ближний Восток, Терроризм

Заявление о конфликте интересов: Автор заявляет об отсутствии конфликта интересов.

\section{История статьи:}

Поступила в редакцию: 15.04.2021. Принята к публикации: 31.05.2021.

\section{Для цитирования:}

Отман A.X. Политическая система Саудовской Аравии и расчеты нового баланса на Ближнем Востоке // Вестник Российского университета дружбы народов. Серия: Государственное и муниципальное управление. 2021. Т. 8. № 3. C. 336-346. DOI: 10.22363/2312-8313-2021-8-3-336-346

\section{Информация об авторе:}

Абдуллах Хазаа Отман - аспирант кафедры политического анализа и управления Российского университета дружбы народов (ORCID ID: 0000-0003-1875-8867) (e-mail: abdollah.othman1985@gmail.com). 